\title{
ICTs for improving Iran's national Competitiveness
}

\author{
Maria Abdollahpouri \\ Iranian Association of Information and Communication Technologies \\ (mariaabdollahpouri@gmail.com) \\ Received 25 August, 2017
}

\begin{abstract}
This journal is licensed under a Creative Commons Attribution-NonCommercial 4.0 International License (CC-BY-NC). Articles can be read and shared for noncommercial purposes under the following conditions:

- BY: Attribution must be given to the original source (Attribution)

- NC: Works may not be used for commercial purposes (Noncommercial)

This license lets others remix, tweak, and build upon your work non-commercially, and although their new works must also acknowledge you and be non-commercial, they don't have to license their derivative works on the same terms. License Deed Link: http://creativecommons.org/licenses/by-nc/4.0/

Legal Code Link: http://creativecommons.org/licenses/by-nc/4.0/legalcode

$A B C$ Research Alert uses the CC BY-NC to protect the author's work from misuse.
\end{abstract}

\begin{abstract}
There is fierce competition among firms to target larger markets. Effective competition and achieving advantage over competitors are closely associated with the concept of competitive advantage. Various sources of competitive advantage are found in the literature. However, Information and Communication Technologies (ICTs) are increasingly becoming the center of attention for creating competitive advantage both at firm and country level. A large group of firms in every country are Small and Medium Enterprises (SMEs). SMEs are widely known as enablers of business and economic growth; nevertheless, they constantly face challenges in competition. In this study, ICTs are introduced as a strategy for SMEs to improve their competitiveness. It is suggested that promoting competition among SMEs could lead to a higher performance in competitiveness at country level. The present research concludes by the strong potentiality of ICTs to improve Iran's national competitiveness through making the home market more competitive for its SMEs.
\end{abstract}

\section{Keywords}

ICT, Competitive Advantage, National Competitiveness, Diamond Model, SMEs

\section{Introduction}

Businesses and industries operate in competitive environments. Competition is known as the driving force of the market that has impact on productivity growth (Porter \&Sakakibara, 2004; Olperet al., 2014), economic efficiency (Mukhopadhyay, 2012), productivity and market power (Bridgman, 2010; De Loecker\& Van Biesebroeck, 2015), supply chain (He et al., 2013), management quality (Bloom et al., 2015), and innovation (Tang, 2006; Godfrey, 2008; Bos et al., 2013). Competitiveness is the ability or level of performance of a firm or country to stand out when competing with other firms or countries. Promoting effective competition and achieving distinct advantage are so closely aligned that they inevitably lead to a concept called 'competitive advantage'. 
Sources of competitive advantage are linked to various contexts, from human capital to technological attainment. With their rapid growth, Information and Communication Technologies (ICTs) are increasingly becoming the centre of attention for delivering competitive advantage and the literature acknowledges the adoption of ICTs as a significant source of competitive advantage (Ong \& Ismail, 2008; Rohrbeck, 2010; Sakchutchawanet al., 2011; Kushwaha, 2011; Sweeney \&Viehland, 2011; Adebambo, \&Toyin, 2011; Mihalic\&Buhalis, 2013).According to the Organisation for Economic Co-operation and Development (OECD, 2014), ICTs have been adopted by all sectors of the economy to extend market reach, increase productivity, improve performance and reduce operational costs. Firms frequently integrate ICTs to redesign business processes and bolster their competitive advantage (Phan, 2003).

An important category of firms are Smalland Medium Enterprises (SMEs). SMEs are constantly encountering competition challenges (Parnell et al., 2015) while struggling to survive in severely competitive environments both at national and global scale (Gbolagadeet al., 2013 cited in Uchegbulam\&Akinyele, 2015). One of the strategies that can be applied for SMEs to deal with competition challenges is the adoption of ICTs in a way that will boost the efficiency and competitiveness of such enterprises (Ongori\&Migiro, 2010). By facilitating business processes, managing and optimizing resources, information and decision-making, ICTs is considered an important source for competitive advantage in enterprises. Therefore, it is essential that SMEs are encouraged to use new ICT solutions and applications so as to achieve competitive success (Donrrosoroet al., 2001 cited in Cuevas-Vargas et al., 2015).ICT has also been at the centre of attention for nations' competitiveness at global level; it is explicitly one of the pillars of the global competition framework and is also implicitly related to the other pillars.

\section{LITERATURE REVIEW}

The World Economic Forum (WEF, 2014), which provides yearly reports on every country's position in global competitiveness, defines competitiveness as "the set of institutions, policies, and factors that determine the level of productivity of a country" (p. 4). Aspects of competitiveness are understood in a set of ' 12 pillars' composing the Global Competitiveness Index (GCIs). These pillars are set as: 1) institutions, 2) infrastructure, 3) macroeconomic environment, 4) health and primary education, 5) higher education and training, 6) efficient goods markets, 7) labour market efficiency 8) financial market development, 9) technological readiness, 10) market size, 11) business sophistication, and 12) innovation.

It is obvious that a country's performance in competitiveness is a result of the competitiveness within the country. That is, competitiveness of a country's enterprises, companies and firms is reflected in the country's performance at national level. Therefore, to investigate a nation's competitiveness, the need for a framework that links the two levels seems necessary. In this research, Porter's Diamond Model is used for carrying out the analysis for national competitiveness and to make connections between competition at enterprise and national levels.

\subsection{Porter's Diamond Model}

Porter (1990) mentions that competitive advantage is generated and sustained through localized processes in a home environment that is dynamic, challenging, innovative and 
progressive in its competitive patterns. He identifies four actors that contribute to competitive advantage at industry level within a nation: 1) Factor condition, 2) Demand conditions, 3) Related and supporting industries, 4) Firm strategy, structure and rivalry. Government and chance are two other elements considered as variables in the Diamond Model. The rationale of the model is that these are in fact firms, not nations that compete in international markets; therefore, the way firms generate and sustain competitive advantage is the key point to explain a nation's achievement in competition.

\subsubsection{Factor Conditions}

The first component of the diamond model is a nation's position in production. Porter (1990) found that a country's possession of factor conditions, or factor of production such as infrastructure and skilled labour, is necessary to compete in a particular industry. He considers two types of factors; basic and advanced. Basic factors are in fact endowments of a nation and are identified by the abundance, quality and accessibility of a country's land, natural and physical resources, climate, geographic location and unskilled labour. However, the influence of these factors on building competitive advantage depends on the effectiveness of deployment within an industry. Advanced factors are more complicated that basic ones because they involve the nation's capital of skilled labour, knowledge, transportation and communication infrastructure, research facilities, innovation power and technological resources. Advanced factors are regarded as important sources of competitive advantage and may be generated through research, innovation and training.

\subsubsection{Demand Conditions}

Demand condition refers to the domestic market for an industry in which it acts. The point is that an industry's production or service is influenced by the demand in the home market. The main characteristics here are the strength and sophistication of the customer demand in the domestic market. Pressure on home companies would lead to gaining competitive advantage for them (Hill, 2009). Companies are innovative and efficient, and improve the quality of their products better when they undergo more pressure from their customers in a demanding local market. This will foster gaining sophisticated competitive advantage against foreign rivals.

\subsubsection{Related and Supporting Industries}

Presence of industrial clusters, or related suppliers, competitors and complementary firms is highly beneficial for an industry to build competitive advantage. In the diamond model, related industries are referred to as industries that can involve complementary products, like technological know-how, or employ similar skills and/or technology in various aspects, like manufacturing, marketing, distribution and services to the core industry (Lahti, 2010). While claiming that the diamond's systematic nature promotes clusters of competitive industries, Porter (1998) adds that clusters affect competition by increasing productivity, innovation and stimulating the creation of new businesses.

\subsubsection{Firm Strategy, Structure and Rivalry}

The way firms in a nation are created, organized and managed is widely influenced by the nation's context and conditions (Porter, 1990). These conditions also influence the domestic rivalry in a nation. As suggested by Porter, competitiveness in a specific industry is a result of combining organizational modes and management practices that are dominant in a country. 
The fact that managerial systems, organizational modes and goals, individual motivation and achievements, and pressures of local rivalry varies considerably between nations results in "dissimilar international strategies" of the firms (Morschett, 2015, p: 179) and would create competitive advantage for a nation (Porter, 1990).

\subsubsection{Government and Chance}

Pointing out the fact that only firms create competitive advantage, not governments, Porter mentions that governments have an inherently partial role that would lead to success only when they work in tandem with desirable conditions in the diamond model. The government's main role here is as a catalyst that encourages companies to high levels of competitive performance.

Porter also recognized the role of chance in building competitive advantage. Examples of chance here could be points such as a dramatic change in the global, financial market or exchange rate, major technological advancements, new inventions, disruptions in input costs e.g. shock in oil price, war or foreign governments' political decisions (Rugman \& Collinson, 2012).

\section{METHODOLOGY}

Although plenty of literature resources can be found on firm competitiveness and national competitiveness, there seems to be a gap in knowledge and deep analysis of the connection between the two. Porter's famous theory and model of national competitiveness, the Diamond Model (Porter, 1990), is a highly-regarded theory in academia, industry and business that investigates the drivers of national competitiveness. However, there is a research gap in applying the diamond model as the analytical framework for explaining its own theory, i.e. explaining the link between competitiveness at firm level and national level. According to the theory, strong domestic rivals and highly localized processes within a country can lead to creating and sustaining national competitive advantage in global competition. The aim of this research is to set the stage for taking practical steps towards improving Iran's competitive status.

This research is conducted based on a qualitative approach which is one of the two major approaches to research. By adopting a qualitative approach, this research has utilized an open and flexible research design for collecting and interpreting data, therefore, making the researcher a part of the research process. Qualitative research is not only restricted to providing knowledge or insight. Its objective can be to also generate knowledge or change the matter under research in order for it to be practically relevant. This means that solutions are created and developed to be relevant to practical problems (Flick, 2007). This fulfils the main goal of this research which is attempting to provide a realistic and practical solution to the low level of national competitiveness of the country case study.

The case study approach in qualitative research facilitates the exploration of a particular phenomenon within its context (Baxter \& Jack, 2008). Case study ensures that the subject has been well explored and that the nature of the phenomenon is uncovered. The case study of this research is particularly SMEs in Iran as a developing country. The research focuses on SMEs for the following reasons: 
1. They have an integral role in the economy of the developing countries;

2. Low complexity and rigid bureaucracy; and

3. Rapid growth of new technologies in the enterprise (Hanafizadeh et al., 2012).

Therefore, SMEs prove to be suitable enough as the focus is on the adoption of ICT as a technology with a variety of uses and applications.

\section{ANALYSIS}

\subsection{SMEs in Iran}

There is no consensus on the very definition of SMEs in Iran. Various organizations, institutions and ministries use their own criteria to describe and categorize SMEs connected to them. For instance, the Ministry of Agriculture and the Ministry of Industry and Mines categorize enterprises those with less than 50 employees as SMEs while the Statistical Office of Iran considers enterprises those with less than 10 employees as SMEs.

Regardless of the category, SMEs in Iran face barriers similar to those in other developing or even developed countries. The main barrier to the development of SMEs in Iran has been recognized as the lack of access to much required information (Molanezhad, 2010). Such types of information are related to:

Marketing (information about the domestic and foreign markets, pricing structures etc.).

Financial or technological positions of SMEs required to attract appropriate investors.

Fields of science and technology.

Suppliers and buyers (for raw materials).

Bearing the issue of competitiveness in mind, it is obvious that gathering the above information could be improved by a wider and more targeted use of ICT in enterprise. This research, therefore, investigates the potential for enhancing competitiveness in Iranian SMEs without focusing on a specific industry. If this is successfully analysed, the present study also sets the stage for further research in investigating SMEs in specific industry sectors.

\subsection{Iran, ICTs and Diamond Model}

According to WEF (2015), Iran's insufficient capacity to innovate and inadequately skilled work forces are identified as problematic factors. The importance of an educated population and the efficiency of the labour forces have also been stressed in this report. Here, the important factors that can be considered regarding SMEs are advanced factors such as skilled and educated labour, knowledge and innovation.

\subsubsection{Factor Conditions}

\subsubsection{ICTs and KM}

Knowledge Management (KM) can be implemented in all sections of an organization, including every department and sub-department in order to foster knowledge-based development (Akhavan\&Jafari, 2006; Akhavan et al., 2006) and can create competitive advantage for Iranian SMEs (Gholipour et al., 2010). However, SMEs in Iran have not been able to manage all the aspects of KM at the same time (Valmohammadi, 2010). Therefore, it is crucial to investigate how KM could be improved in Iranian SMEs. Here, the prominent role of ICTs in KM could be created by facilitating knowledge sharing and management. Using ICT-based KM also paves the way for organizational effectiveness by: 
Facilitating communication;

Analyzing data;

Developing tools applicable to KM (storage support, document management systems);

Improving internal processes (Human Resources Management (HRM) and Enterprise Resource

Planning (ERP)) and enterprise systems;

Filtering personalized information;

Developing information systems and knowledge maps;

Providing learning support (e-learning); and

Providing external collaborative connections e.g. Electronic Customer Relationship

Management (eCRM), firm/industry specific applications etc. (Subashini et al. 2012;

García-Álvarez, 2015).

\subsubsection{ICTs and Innovation in SMEs}

Kamalian et al. (2011) make the point that the uncompetitive nature of SMEs in Iran is a consequence of the lack of innovation in them. Cloud is an example of the application of ICTs that has the ability to foster innovation in productivity and competitiveness while reducing harmful environmental impacts (EU, 2012). Iran requires to ensure that a larger number of SMEs benefit from the innovation created by novel cloud applications and services. Ghaffari et al. (2014) make the point that Iranian SMEs can dramatically progress in their business trends by adopting cloud technology. They add that lower investment on hardware and infrastructure creates easier scalability and makes more efficient use of computing resources; therefore, these are some of the benefits Iran can take advantage of via cloud technology.

\subsubsection{Demand conditions}

Sophisticated demand market is created by customers' high demand for better products and services and their involvement in shaping the demand market. Little evidence in the literature can be found regarding the connection between e-business- the application of ICTs in business activities and processes- and customer sophistication. In some cases, customer sophistication is described as customers demanding higher levels with immediate services over multiple access channels (Pan \& Lee, 2003). Bearing this aspect in mind, ICTs and e-business have provided customers with faster services (e.g. online shopping and other e-commerce services) and personalized product and service innovation (Barrett et al., 2015).

CRM is an important factor in knowing customers' needs, handling their increasing expectations and preserving their loyalty. Regarding the demand condition element of the diamond model, the role of electronic CRM in assisting companies in taking proper actions in accordance with the needs of their customers should be considered. GilaniNia et al. (2013) conducted a case study based on evidence from Iranian SMEs to assess the impact of utilizing e-CRM on creating competitive advantage. They found that the low use of e-CRM systems led to low levels of competitive advantage being obtained by the firms. Considering the direct relationship between using e-CRM and generating competitive advantage (Bahrami, 2012), Iranian SMEs can profit from the advantages created by effectively utilizing e-CRM. Example of these benefits are:

Delivering competitive strategy to ensure competitive advantage;

Cost-effective marketing and promotions;

Reduction with transaction and overhead costs;

Spotting the necessity for data and communication improvement;

Quick and easy access to customer-related documents;

Customizing cross-sells and up sells;

Delivering better customer service (Kumar \& Kumar, 2014; Balakrishnan, 2015). 
4.2.3. Related and Supporting Industries

4.2.3.1. E-clustering

Technological and communication advancements brought about by ICTs have made it much easier for related industries to cooperate effectively. While the obvious benefit of clusters is the physical proximity (DeWitt et al., 2006), ICTs have managed to cut the short distances and have defined new forms of clusters known as 'e-clusters'. E-cluster is an e-business network that;

1) Integrates with companies in Telecommunication, Information Technology, Multimedia,

Entertainment and Security (TIMES) sectors;

2) Builds e-channels and e-supply for procurement and distribution; and

3) Applies innovation, knowledge, intellectual property and national strength to create global competitive advantage (Davidović, 2014).

E-clusters are important for regional development in order to connect firms, businesses and industrial sectors (Adebanjo\&Michaelides, 2010), and so, we expect that Iranian SMEs could take benefit from e-clusters to a degree that creates competitive advantage. Many Iranian SMEs are burdened with financial restrictions. Therefore, utilizing a more affordable way of e-clusters might be suitable in contexts where financial limitations seriously restrain SMEs from investing in new ICTs solutions. Regarding such a common issue with SMEs as a whole, Kawa and Ratajczak-Mrozek (2014) propose e-cluster as a network structure - i.e. the use of cloud community in e-clusters. In this way, SMEs are given the ability to automatically capture and exchange information within a particular network of enterprises. Bearing in mind the relatively low cost of Internet access, SMEs in supply, distribution, manufacturing and retail can closely and effectively work in collaboration across the cloud networks in the clusters.

\subsubsection{Firm Strategy, Structure and Rivalry}

A vast amount of literature highlights how ICT can impact firm strategy, structure and rivalry. Regarding the 4th element of the diamond model, it is required to have a narrower insight into a particular industry to find out how ICTs impact processes and practices in firm strategy, structure and rivalry. For example, a specific industry might focus on management systems and procedures while another may concentrate on production activities. Apparently, there are various industry or business activities which are centred around a particular strategy or based upon a particular structure and, therefore, the impact of ICTs for each of these should be investigated with respect to the particular area.

Firm strategy, structure and rivalry can be also considered in close relationship with government, as the role of government is significant in formulating regulations that organizes firms' creation and domestic rivalry. This becomes even more necessary for a country like Iran in which almost all the structures and rules in industry, business and trade are established by the government.

\subsubsection{Government}

The logical approach regarding the government element of the Diamond and ICTs would be to reason that governments can impact the way ICTs are utilized by firms and enterprises. Depending on what extent the government supports or discourages adopting ICTs, the level of the competitiveness created by ICTs would vary. Having an important role in incentivizing competitiveness in the country, government policies and regulations can positively contribute to the progress of the adoption and use of ICTs. 
According to Fathian et al. (2008), positive changes regarding ICT have been more tangible in private, non-profit enterprises rather than in governmental organizations. E-readiness of private SMEs is much more advanced in comparison to governmental corporations. The governments' primary role is to provide enough financial support for encouraging SMEs to effectively use ICTs. Iran's government can support and even speed up the adoption and process of ICTs, e.g. Internet advertising, through enacting obligation policies. In other words, the government may consider, for example, online marketing and advertising as an obligatory regulation at the time SMEs develop their business plans (Hanafizadeh et al., 2012). It can also encourage the utilization of ICTs by offering loans and promotions to enterprises that have active and effective roles in campaigns for Internet advertising. Such policies can be expanded to other areas that include the use of ICTs by SMEs in order to ensure the optimum use of digital technology in the country.

The government should also ensure an effective level of competition in its active sectors. Although Iran's government has made efforts in opening up the economy to competition, this process is very slow. According to Molanezhad (2010), Iran's system of subsidies, the allocation of licenses and resources, provides only limited competition in the majority of its industries. This has led to the lack of effective competition among Iranian industries to develop new products and services or to even improve the existing ones.

\subsubsection{Chance}

Chance can be interpreted as a set of events that cannot be controlled, prevented or managed by firms. These events include technological advancements, inventions and innovations. We may interpret the role of ICTs here as how foreign competitors use ICTs and to what extent they create advantage through the effective utilization of it. For example, foreign companies might make huge benefits from producing and commercializing their technological breakthroughs or ICT-related innovations that could disrupt the dominant status of the local market. Another assumable case for chance would be the role of ICTs in social media in political movements or decisions made by foreign governments or international authorities. Regarding Iran, heavy sanctions imposed against commerce, imports (including the provision of materials for domestic purpose), exports and foreign currency transactions still have a significant role not only on SMEs, but also on any active industrial, trade or business entity. With the aid of digital communication networks, media and Internet channels, enterprises do not find respite to adjust themselves to the rapid changes and disruptions. As a consequence, domestic firms will be exposed to undergo, and not necessarily withstand, the shocks of adversity in the home market.

\subsection{Iran, ICT \& Global Competitiveness}

The first pillar of competitiveness is defined as 'institutions'. An important aspect of an institutional environment is the government's attitudes towards private sectors and the efficiency of market operations (WEF, 2014). This goes back to the government element of the diamond model and the way the government can influence the environment in which SMEs operate by encouraging and supporting the effective use of ICTs along with optimizing the organizational modes, management practices and competition regulations.

The second pillar is 'infrastructure'; here, the availability of a stable and extensive telecommunications network is emphasized. Clearly, such a network would allow a free and 
rapid information flow. This, in turn, would increase the economic efficiency by ensuring that businesses and economic actors communicate effectively while having access to available required information (ibid). This particularly proves to be important when taking the clusters and related industries into account.

The stability of macroeconomic environments, which is the third pillar, is important for businesses as well as a country's overall competitiveness. In Iran's case, the government dominates the creation, organization and management of the businesses, enterprises and economic actors. Therefore, the rivalry and environment in which SMEs act are dependent on the macroeconomic environment generated and controlled by the government.

The fourth and fifth pillars are primary education and higher education and training, respectively. In relation to higher education and training, the quality of education, staff training and constant vocational and on-the-job training are the most important factors that should be considered (ibid). The seventh pillar, labour market efficiency, can also be considered relevant to having well-educated labour by enhancing the role of ICTs in organizational and professional learning.

The efficiency of goods market is the sixth pillar of competitiveness. Efficient trade and competition in the domestic market is achieved when the best environment for the exchange of goods is created (ibid). Such an environment is created when products and services are offered in the market in proportion to the country's supply and demand market. This is in close relationship with the second and third element of the diamond model - demand conditions, and related and supporting industries. As mentioned earlier, ICTs can develop the sophistication of the demand market as well as creating effective relationships between the customers in the demand market and the product and service providers.

The eight pillar, financial market development, emphasizes business investments, available capital for private sector and efficient financial allocations to domestic sectors and the economy actors entering from abroad. Again, this is dependent on the role and influence of the government in defining regulations for entrepreneurial and business investments. Here, a general view is assumable that government has the most influential role in attracting domestic and foreign investments, and fostering financial development in the market. However, the focus on ICTs and SMEs in investment and financial development of the market has not been considered, as it requires deeper analysis, which is out of the scope of this study.

The ninth and twelfth pillars are technological readiness and innovation, respectively. The current research was conducted to examine the role of ICTs, as the featured example of today's technology, in improving national competitiveness. Therefore, all the analysis conducted in the analysis section may apply here.

Market size makes the tenth pillar of competitiveness. Although Porter (1990) puts more emphasis on the sophistication of the market rather than the size of it, Morschett et al. (2015) highlight the importance of a large market. Market size has also been noted as one of the factors that influences the competition (Melitz and Ottaviano, 2008). Lasch et al. (2013) make the point that ICTs are particularly driven by customers and the market, and therefore the local market size is an indicator of business opportunities. Although SME-specific in 
formation about the role of ICTs on market size was not found for Iran nor a developing country, there is more general data that can be drawn upon.

According to a report provided by the Centre for Retail Research (CRR, 2015), e-commerce is the most rapidly growing retail market in Europe with an expanding pace of 14.2 times faster than conventional outlets. However, in 2013, Asia-Pacific had the strongest, worldwide e-commerce network as its turnover of \$567.3bn excelled Europe and North America with $\$ 482.3 \mathrm{bn}$ and $\$ 452.4 \mathrm{bn}$, respectively (ECEU, 2015). Such growth is largely driven by a rapid increase of computer, internet and e-commerce market penetration (Capgemini, 2013; ECEU, 2015). Therefore, it can be concluded that the role of ICT application has strong capability in creating large markets and this, in turn, affects the competition.

The eleventh pillar is referred to as 'business sophistication'. There are two elements regarding business sophistication that are closely interrelated; these are the quality of a country's business network and the quality of the operation of its individual enterprises (WEF, 2014). In relation to the present study, the first element is related to the extent to which a country provides good business networks for its local firms, suppliers and related businesses and industries through the application of ICTs. The second element relates to the extent to which ICTs create business sophistication at enterprise level. As mentioned by Forman (2005, cited in Sadowski, 2014) a wide variety of new ICT solutions and services indicate the technological sophistication of a firm. Ogrean et al. (2010) consider e-commerce and e-business, among all the applications of ICTs, as the most relevant ICT services that canlink technological readiness to business sophistication. Therefore, the reasoning could be that technological readiness brings about technological sophistication by providing multiple services at a time. Inevitably, this would lead to business sophistication since each of the services or solutions, particularly e-commerce and e-business, perform a set of business activities or processes.

\section{CONCLUSION}

It has been discussed that a good level of competitiveness within the country paves the way for Iran to gain and sustain a stronger position in global market. We investigated how the application of ICTs in Iranian SMEs has the potential to improve the country's position in global competitiveness. Using Porter's Diamond Model and the Global Competitiveness Index, it has been demonstrated that establishing and improving the use of ICTs by SMEs provides suitable conditions for fostering competition; leading to enhancing competitiveness within the country. The following table (Table 1) summarizes the whole analysis for this research.

Table 1: Summary of the Research Analysis
\begin{tabular}{|c|l|l|}
\hline $\begin{array}{c}\text { Competitiveness } \\
\text { Pillar }\end{array}$ & \multicolumn{1}{|c|}{ Diamond Element } & \multicolumn{1}{c|}{ Explanation } \\
\hline Institutions & Government & $\begin{array}{l}\text { Providing financial support and supportive regu- } \\
\text { lations. }\end{array}$ \\
\hline Infrastructure & $\begin{array}{l}\bullet \quad \text { Government } \\
\text { Related and supporting in- } \\
\text { dustries }\end{array}$ & $\begin{array}{l}\text { Ensuring reliable access to communication networks and } \\
\text { effective communication across e-clusters. }\end{array}$ \\
\hline $\begin{array}{c}\text { Macroeconomic } \\
\text { environment }\end{array}$ & $\begin{array}{l}\text { Government } \\
\text { Fivalry strategy, structure and } \\
\text { rivective use of ICTs by SMEs. }\end{array}$ & $\begin{array}{l}\text { Providing an effective competitive environment for } \\
\text { SMEs and business/industry factors to compete in. }\end{array}$ \\
\hline
\end{tabular}




\begin{tabular}{|c|c|c|}
\hline Primary education & \multirow[t]{2}{*}{ Factors conditions } & \multirow[t]{2}{*}{$\begin{array}{l}\text { Ensuring effective integration and the use of ICTs in } \\
\text { learning, both in higher education and professional areas. }\end{array}$} \\
\hline $\begin{array}{l}\text { Higher education } \\
\text { and training }\end{array}$ & & \\
\hline $\begin{array}{l}\text { Efficient goods } \\
\text { markets }\end{array}$ & $\begin{array}{l}\text { - Demand conditions } \\
\text { - Related and supporting in- } \\
\text { dustries }\end{array}$ & $\begin{array}{l}\text { Use of ICTs to increase the level of demand } \\
\text { market in terms of sophistication. } \\
\text { Use of ICTs for maintaining effective relation- } \\
\text { ships between customers and product/service providers. } \\
\text { - Use of ICTs for maintaining effective communi- } \\
\text { cation between the connected market actors. }\end{array}$ \\
\hline $\begin{array}{c}\text { Labour market } \\
\text { efficiency }\end{array}$ & Factors conditions & $\begin{array}{l}\text { Ensuring the effective use of ICT applications in organ- } \\
\text { izational and professional training in SMEs. }\end{array}$ \\
\hline $\begin{array}{c}\text { Financial market } \\
\text { development }\end{array}$ & Government & $\begin{array}{l}\text { Providing financial support and easy regulation for } \\
\text { SMEs entrepreneurship. }\end{array}$ \\
\hline Market size & Demand conditions & $\begin{array}{l}\text { Exploring larger markets by establishing strong } \\
\text { e-commerce marketplaces. }\end{array}$ \\
\hline $\begin{array}{l}\text { Technological } \\
\text { readiness }\end{array}$ & All the elements of the Diamond & $\begin{array}{l}\text { Improving competitiveness both at firm and national } \\
\text { level. }\end{array}$ \\
\hline Innovation & & \\
\hline $\begin{array}{l}\text { Business sophistica- } \\
\text { tion }\end{array}$ & $\begin{array}{l}\text { - Firm strategy, structure and } \\
\text { rivalry } \\
\text { - Related and supporting in- } \\
\text { dustries }\end{array}$ & $\begin{array}{l}\text { Creating and increasing business sophistication through } \\
\text { the application of e-business and e-commerce by SMEs. }\end{array}$ \\
\hline
\end{tabular}

This research attempted to focus on the positive potential of ICTs to improve national competitiveness. However, there are, and would definitely be, barriers associated with SMEs implementing ICTs at a wider level in order to increase national competitiveness. Further literature can be found on the existing barriers to adoption of ICTs by Iranian SMEs (see Houraliet al., 2008; Sameni \& Khoshalhan, 2009; Hajliet al., 2014; Yasin et al., 2014). For instance, ICT solutions and the technological sophistication brought by it should be cost-effective in order to make it possible for firms to implement it. Other barriers, whether related to cost or technology requirements, are still challenging the majority of SMEs across the country and within various industries and sectors, and thus, require their own study. Therefore, it would be useful for further research to be conducted in order to examine the problems affecting the implementation of ICTs in the forms mentioned in this research.

\section{References}

Adebambo, S., \&Toyin, A. (2011) 'Analysis of information and communication technologies (ICT) usage on logistics activities of manufacturing companies in Southwestern Nigeria`, Journal of Emerging Trends in Economics and Management Sciences (JETEMS), Vol. 2, No. 1, pp. 66-72.

Adebanjo, D. \&Michaelides, R. (2010) `Analysis of Web 2.0 enabled e-clusters: A case study`, Technovation, Vol. 30, No. 4, pp. 238-248.

Akhavan, P. \&Jafari, M. (2006) 'Critical success factors of knowledge management implementation at a national level', the journal of information and knowledge management systems, Vol. 36, No. 1, pp. 52-66.

Akhavan, P., Jafari, M \&Fathian, M. (2006) 'Critical success factors of knowledge management systems: A multi-case analysis`, European Business Review, Vol. 18, No. 2, pp. 97-113.

Bahrami, M., Ghorbani, M., \&Arabzad, S. M. (2012) 'Information technology (IT) as an improvement tool for customer relationship management (CRM)`, Procedia-Social and Behavioral Sciences, Vo. 41, pp. 59-64.

Balakrishnan, I.S. (2015) 'Factors influencing the use of contraception`, International Journal of Research in Management \& Social Science, Vol. 3, No. 1, pp. 87-91.

Barrett, M., Davidson, E., Prabhu, J., \& Vargo, S. L. (2015) 'Service innovation in the digital age: key contributions and future directions`, MIS Quarterly, Vol. 39, No. 1, pp. 135-154. 
Baxter, P., \& Jack, S. (2008) 'Qualitative case study methodology: Study design and implementation for novice researchers`, the qualitative report, Vol. 13, No. 4, pp. 544-559.

Bloom, N., Propper, C., Seiler, S. \& Van Reenen, J. (2015) 'The Impact of Competition on Management Quality: Evidence from Public Hospitals', Review of Economic Studies, Oxford journals, Vol. 82 (2), pp. 457-489

Bos, J. W., Kolari, J. W., \& Van Lamoen, R. C. (2013) 'Competition and innovation: Evidence from financial services`, Journal of Banking \&Finance,Vol.37, No. 5, pp. 1590-1601.

Bridgman, B. (2010) Competition and Productivity, US Bureau of Economic Analysis, Washington.

Capgemini (2013) Evolving E-Commerce Market Dynamics Changing Merchant Payment Needs and the Impact on Banks, Capgemini, New York.

CRR. (2015) Online Retailing: Britain, Europe, US and Canada 2015, Centre for Retail Research [Online], Available: http://www.retailresearch.org/onlineretailing.php [Accessed: 28 September 2015]

Cuevas-Vargas, H., Enríquez, L. A., Adame, M. G., \& Servin, J. L. (2015) `The use of ICTs and its relation with the competitiveness of Mexican SMEs`, European Scientific Journal, Vol. 11, No. 13. pp. 294-310.

Davidović, M. (2014) 'Development of e-clusters`, Information and Communication Technology, Electronics and Microelectronics (MIPRO), pp. 1563-1568.

De Loecker, J. \& Van Biesebroeck, J. (2015) Effect of International Competition on Firm Productivity and Market Power, the Oxford Handbook of Productivity Analysis, Oxford.

DeWitt, T., Giunipero, L. \& Melton, H. (2006) 'Clusters and supply chain management: the Amish experience`, International Journal of Physical Distribution \& Logistics Management, Vol. 36, No. 4, pp. $289-308$.

Donrrosoro, I., García, C., González, M., Lezámiz, M., Matey, J., Moso, M., \&Unzuela, M. (2001) The management model of SMEssuccess [El modelo de gestión de las PYMEs vascas de éxito], Edit Knowledge Cluster (Portal Management) and PMP Editions [Edita Cluster del Conocimiento (Portal de Gestión) y ediciones PMP], Bilbao.

ECEU. (2015) With a turnover of $\$ 567.3$ billion, Asia-Pacific is the largest e-commerce region in the world, E-CommerceEurope[Online],Available:

http://www.ecommerce-europe.eu/news/2015/with-a-turnover-of-567.3-billion-asia-pacific-is-the-large st-e-commerce-region-in-the-world [Accessed: 28 September 2015]

EU. (2012) ICT Innovation for The Factories of the Future, European Commission [Online], Available: http://cordis.europa.eu/fp7/ict/micro-nanosystems/docs/report_from_workshop_on_ict_innovation_ffo r_the_factories_of_the_future.pdf [Accessed: 12 August 2015]

Fathian, M., Akhavan, P., \&Hoorali, M. (2008) `E-readiness assessment of non-profit ICT SMEs in a developing country: The case of Iran`, Technovation, Vol. 28, No. 9, pp. 578-590.

Flick, U. (2007) Designing Qualitative Research, Sage, London. .

Forman, C. (2005) `The Corporate Digital Divide: Determinants of Internet Adoption`, Management Science, Vol. 51, No. 4, pp. 641-654.

García-Álvarez, M.T. (2015) `Analysis of the effects of ICTs in knowledge management and innovation: The case of Zara Group`, Computers in Human Behaviour, Vol. 51, Part B, pp. 994-1002.

Gbolagade, A., Adesola, M.A. \&Oyewale, I.O. (2013) 'Impact Of Marketing Strategy On Business Performance`, IOSR Journal Of Business and Management, Vol. 11, No. 4, pp. 59-66.

Ghaffari, K., Delgosha, M. S., \&Abdolvand, N. (2014) 'Towards Cloud Computing: A SWOT Analysis on its Adoption in SMEs', International Journal of Information Technology Convergence and Services (IJITCS), Vol. 4, No. 2, pp. 13-20.

Gholipour, R, Jandaghi, G. \&Hosseinzadeh, S.A.A. (2010) `Explanation of knowledge management enabler as a latent variable: A case study of SMEs in Iran`, African Journal of Business Management, Vol. 4, No. 9, pp. 1863-1872.

GilaniNia, S., Balaei, S., \&Niyari, F. S. (2013) 'Impact of ECRM on the Create Competitive Advantage in Hotels of Sarein`, Arabian Journal of Business and Management Review, Vol. 3. No. 4, pp. 77-85.

Godfrey, N. (2008) Why is Competition Important for Growth and Poverty Reduction?, Department for International Development, London.

Hajli, N., Sims, J., \& Shanmugam, M. (2014) `A practical model for e-commerce adoption in Iran`, Journal of Enterprise Information Management, Vol. 27, No. 6, pp. 719-730.

Hanafizadeh, P., Behboudi, M., Ahadi, F., \&GhaderiVarkani, F. (2012) 'Internet advertising adoption: a structural equation model for Iranian SMEs`, Internet Research, Vol. 22, No. 4, pp. 499-526.

He, Z., Wang, S. \& Cheng, T.C.E. (2013) 'Competition and evolution in multi-product supply chains: An agent-based retailer model', International Journal of Production Economics, Vol. 146 (1), pp. 325-336. 
Hill, C. W. L. (2009) International business: Competing in the global marketplace (7th ed.), McGraw-Hill/Irwin, Boston.

Hourali, M., Fathian, M., Montazeri, A., \&Hourali, M. (2008) `A model for e-readiness assessment of Iranian small and medium enterprises`, Journal of Faculty of Engineering, Vol. 41, No. 7, pp. 969-985.

Kamalian, A., Rashki, M. \&Arbabi, M.L. (2011) `Barriers to Innovation among Iranian SMEs`, Asian Journal of Business Management, Vol. 2, No. 3, pp. 79-90.

Kawa, A. \&Ratajczak-Mrozek, M. (2014) 'Cloud Community in Logistics e-Cluster`, in Intelligent Information and Database Systems, N.T. Nguyen, B. Attachoo, B. Trawi`nski, \& K. Somboonviwat (Eds.), Springer International Publishing, pp. 495-503.

Kumar, M.P. \& Kumar, T.S. (2014) ' E-business: Pros and cons in Customer Relationship Management`, International Journal of Management and International Business Studies, Vol. 4, No. 3, pp. 349-356.

Kushwaha, G.S. (2011) 'Competitive Advantage through Information and Communication Technology (ICT) Enabled Supply Chain Management Practices`, International Journal of Enterprise Computing and Business Systems, Vol. 1, No. 2, p. 3-15.

Lahti, A. (2010) Globalization \& the Nordic Success Model: Part II, Bookboon, London.

Lasch, F., Robert, F., \& Le Roy, F. (2013) `Regional determinants of ICT new firm formation`, Small Business Economics, Vol. 40, No. 3, pp. 671-686.

Lee, S., Kim, K. J., \&Sundar, S. S. (2015) 'Customization in location-based advertising: Effects of tailoring source, locational congruity, and product involvement on ad attitudes`, Computers in Human Behavior, Vol. 51, Part A, pp. 336-343.

Yasin, M., Alavi, J., Czuchry, A., \&Shafieyoun, R. (2014) `An exploratory investigation of factors shaping electronic commerce practices in Iran: Benchmarking the role of technology and culture', Benchmarking: An International Journal, Vol. 21, No. 5, pp. 775-791.

Melitz, M. J., \&Ottaviano, G. I. (2008) 'Market size, trade, and productivity`, The review of economic studies, Vol. 75, No. 1, pp. 295-316.

Mihalic, T., \&Buhalis, D. (2013) 'ICT as a new competitive advantage factor-case of small transitional hotel sector`, Economic and Business Review, Vol. 15, No. 1, pp. 33-56.

Mohammadi, M. R. (2013) 'Ranking of Critical Success Factors of e-procurement in Iranian Automotive Industry`, International Research Journal of Applied and Basic Sciences, Vol. 4, No. 11, pp. 3910-3918.

Molanezhad, M. (2010) A brief review of science and technology and SMEs development in IR Iran, United Nations Conference on Trade and Development (UNCTD), Geneva.

Morschett, D., Schramm-Klein, H., \& Zentes, J. (2015) `Competitive Advantage of Nations and Regional Clusters`, in Strategic International Management, Springer Fachmedien Wiesbaden, Wiesbaden, Germany. pp. 171-197.

Mukhopadhyay, J.P. (2012) Competition in Markets Promotes Economic Efficiency, Institute for Financial Management and Research (IFMR), Chennai.

OECD, (2014) The digital economy, new business models and key features, in Addressing the Tax Challenges of the Digital Economy, OECD Publishing, Paris.

Ogrean, C., Herciu, M., \&Belascu, L. (2010) 'From technological readiness to business sophistication through ICT applications`, Research in Business and Economics Journal, Vol. 2, No. 1. pp. 1-6.

Olper, A., Pacca, L. \&Curzi, D. (2014) 'Trade, import competition and productivity growth in the food industry`, Food Policy, Vol. 49, part 1, pp. 71-83.

Ong, J. W., \& Ismail, H. B. (2008) 'Sustainable competitive advantage through information technology competence: resource-based view on small and medium enterprises`, Communications of the IBIMA, Vol. 1, No. 7, pp. 62-70.

Ongori, H., \&Migiro, S. O. (2010) 'Information and communication technologies adoption in SMEs: literature review`, Journal of Chinese Entrepreneurship, Vol. 2, No. 1, pp. 93-104.

Pan, S. L., \& Lee, J. N. (2003) 'Using e-CRM for a unified view of the customer', Communications of the ACM, Vol. 46, No. 4, pp. 95-99.

Parnell, J. A., Long, Z. \& Lester, D. (2015) `Competitive strategy, capabilities and uncertainty in small and medium sized enterprises (SMEs) in China and the United States`, Management Decision, Vol. 53, No. 2, pp. 402-431.

Phan, D. Dien, (2003) ' E-business development for competitive advantages: a case study', Information \& Management, Vol. 40, No. 6, pp. 581-590.

Porter, M. E. (1990) 'The competitive advantage of nations`, Harvard business review, Vol. 68, No. 2, pp. 73-93.

Porter, M. E., \&Sakakibara, M. (2004) 'Competition in Japan`, Journal of Economic Perspectives, Vol. 18, No. 1, pp. 27-50. 
Rohrbeck, R. (2010) 'Harnessing a network of experts for competitive advantage: technology scouting in the ICT industry`, R\&d Management, Vol. 40, No. 2, pp. 169-180.

Rugman, A. M. \& Collinson, S. (2012) International Business (6th ed.), Pearson, Harlow.

Sadowski, B.M. (2014)Business ICT Adoption and Open Access: The Example of SMEs at Industrial Parks in the Netherlands, the University of Eindhoven, the Netherlands.

Sakchutchawan, S., Hong, C. P, Callaway, K. S. \&Kunnathur, A, (2011) 'Innovation and Competitive Advantage: Model and Implementation for Global Logistics`, International Business Research, Vol. 4, No. 3, pp. 10-21.

Sameni, M. K., \&Khoshalhan, F. (2009) 'E-business adoption in Iranian small and medium enterprises: Analyzing and prioritizing the extra-organizational factors`, paper presented at Portland International Conference on Management of Engineering and Technology (PICMET), Oregon, USA, 2-6 August.

Subashini, R., Rita, S., \&Vivek, M. (2012) `The Role of ICTs in Knowledge Management (KM) for Organizational Effectiveness', in Global Trends in Information Systems and Software Applications, Krishna, P.V., Babu, R. \&Ariwa, E. (Eds.), Springer Berlin, Heidelberg, pp. 542-549.

Sweeney, M., \&Viehland, D. (2011) 'The Use of ICT for Competitive Advantage in the Medical Technical Service Industry`, Journal of Information Science and Technology, Vol. 8, No. 1. pp. 1-15.

Tang, J. (2006) 'Competition and innovation behaviour', Research Policy, Vol. 35, No. 1, pp. 68-82.

Uchegbulam, P. \&Akinyele, S. T. (2015) Competitive Strategy and Performance of Selected SMEs in Nigeria, Covenant University, Ota, Nigeria.

Valmohammadi, C. (2010) 'Identification and prioritization of critical success factors of knowledge management in Iranian SMEs: An experts' view`, African Journal of Business Management, Vol. 4, No. 6, pp.915-924.

WEF. (2014) The Global Competitiveness Report 2014-2015, World Economic Forum, Geneva.

WEF. (2015) What next for Iran's economy?, World Economic Forum [Online], Available: https://agenda.weforum.org/2015/07/what-next-for-irans-economy/ [Accessed: 11 September 2015] 